\title{
TOMASZ PALMIRSKI
}

Uniwersytet Jagielloński

\section{PRAWNOKARNA ODPOWIEDZIALNOŚĆ SĘDZIEGO ŹLE WYPEŁNIAJĄCEGO SWOJE OFFICIUM}

Przekupstwa sędziów (i czasami adwokatów strony przeciwnej) były nieodzownym elementem procesów, zwłaszcza karnych, i znalazły swoje odbicie tak $w$ treści wydawanych incydentalnie ustaw, które miały im zapobiec, jak również w literaturze'. Fakt, że sądownictwo karne zawsze było bardziej spektakularne i zależało od bieżącej sytuacji politycznej, powoduje, iż przeważająca część znanych nam źródeł dotyczyć będzie właśnie przekupstwa sędziów karnych. Należy tu jednak podkreślić, iż sędziowie zasiadający w quaestiones wywodzili się z tej samej klasy co iudices orzekający w sprawach cywilnych's. Stąd też osoba, która jednego dnia orzekała w sprawach karnych, drugiego mogła rozstrzygać w procesie cywilnym, a co za tym idzie, powszechna korupcja w sądownictwie karnym nie mogła nie odbić się również na procesach cywilnych. Trudno bowiem wyobrazić sobie sędziego, który przyjąl korzyść majątkową, by nie-

\section{' J.M. KELLY, Roman Litigation, Oxford 1966, s. 33.}

' Początkowo członkami quaestiones, jak i sędziami orzekającymi w sprawach cywilnych byli wyłącznie senatorowie, od lex Sempronia iudiciaria z 122 r. p.n.e. także ekwici. Wedle lex Aurelia iudiciaria z 70 r. p.n.e. listy sędziów trybunałów karnych składały się po $1 / 3$ senatorów, ekwitów i tribuni aerarii. Taki stan utrzymywal się do roku 46 p.n.e. kiedy to lex Iulia wykluczyła tych ostatnich z zasiadania w quaestiones; por. też M. KASER, K. HACKL, Das römische Zivilprozessrecht', München 1996, s. 49 i n. 
słusznie skazać $\mathrm{w}$ procesie karnym, a pełniąc funkcję sędziego $\mathrm{w}$ procesie cywilnym okazał się człowiekiem nienagannie moralnym.

Najstarsze regulacje dotyczące przekupstwa sędziów zawarte są w Ustawie XII Tablic (Tab. 9,3), której treść przekazuje nam Aulus Gellius ${ }^{3}$. Przytacza on mianowicie rozmowę pomiędzy jurystą Sextusem Caeciliusem i filozofem Favorinusem, w której ten pierwszy o sędzim mówi tak: nisi duram esse legem putas, quae iudicem arbitrumve iure datum, qui ob rem dicendam pecuniam accepisse convictus est, capite poenitur ${ }^{4}$. Z przytoczonego fragmentu wynika więc jasno, iż iudex bądź arbiter, który orzekł zgodnie z życzeniem tego, od którego otrzymał pieniądze, skazywany był na karę śmierci. Jeśli capite poenitur rozumieć jako „skazywany na śmierć”, jest możliwe, że w oryginalnym brzmieniu ustawa określała sposób w jaki wyrok śmierci miał być wykonany ${ }^{5}$.

W powyższym tekście sędzia jest określany jako iudex arbiterve (iudex unus bądź arbiter), co prowadzi do wniosku, że cytowany przepis Ustawy XII Tablic dotyczy wyłącznie sędziego rozstrzygającego spory cywilne. Dla epoki decemvirów bowiem brak jest źródeł potwierdzających udział iudices (a tym bardziej arbitri) w procesie karnym ${ }^{6}$. Inną wskazówką potwierdzającą powyższą tezę jest określenie sądzącego jako iure datus. Istotnie bowiem Ustawie XII Tablic znana była legis actio per iudicis arbitrive postulationem?. Nadto zauważyć należy, że

'Gell. 20,1,7. Por. też M. i J. ZaBŁoccy, Ustawa XII Tablic. Tekst-tlumaczenie - objaśnienia', Warszawa 2003, s. 64, 65.

${ }^{+} \mathrm{Na}$ temat dyskusji toczonej pomiędzy Aulusem Gelliusem a Favorinusem na kanwie cytowanego fragmentu Ustawy XII Tablic, a tyczącej się surowości zawartych w niej przepisów por. J. ZABŁOCKI, Rozważania o procesie rzymskim w 'Noctes Atticae' Aulusa Gelliusa, Warszawa 1999, s. 54, 55.

: W kilku innych przypadkach, w których ustawa przewidywała karę śmierci, sposób jej wykonania jest wskazany; por. Tab. 8,9; 8,14; 8,23.

" Por. B. Santalucia, Alle origini del processo penale romano, «Iura» 35 (1984), s. 52 i n. Termin iudices używany był w procesie karnym na określenie czlonków trybunałów karnych (quaestiones), a więc dopiero od II w. p. n. e. (por. W. LITEWSKI, Stownik encyklopedyczny prawa rzymskiego, Kraków 1998, s. v. iudex).

${ }^{7}$ Co do pochodzenia owej legis actio por. M. KASER, K. HACKL, op. cit., s. 107 i cyt. tam lit. 
określenie iudex arbiterve znajdujemy jeszcze w innych fragmentach tejże ustawys i stąd należy przyjąć, iż jest to wyrażenie oryginalne.

Ponieważ brak jest pewności co do ścisłej granicy pomiędzy zakresem kognicji sędziego i arbitra należy wspomnieć, iż w początkowym okresie po wydaniu Ustawy XII Tablic, w procesie legisakcyjnym, ten ostatni rozpatrywał sprawy z zakresu skarg działowych (działu spadku, spory graniczne, zniesienie współwłasności), jak również wyznaczano go na przykład w celu dokonania oszacowania w przypadku roszczenia niepieniężnego lub obliczenia kary prywatnej według wartości rzeczy".

Wniosek, jaki należy wyciągnąć z użycia frazy iudex arbiterve iure datus, jest taki, iż omawiana regulacja dotycząca przekupnego sędziego znajdowała zastosowanie we wszystkich tych sprawach, które należały zarówno do właściwości iudex unus, jak i arbitra, a więc odnosiła się wyłącznie do sędziów rozpatrujących sprawy cywilne ${ }^{10}$.

W świetle powyższych rozważań nie do utrzymania wydaje się hipoteza, zgodnie z którą oryginalne brzmienie postanowień zawartych w tablicy dziewiątej Ustawy XII Tablic odnosiło się początkowo do sędziów orzekających w sprawach karnych, a dopiero później drogą interpretacji rozciągnięto je również na przypadki przyjęcia korzyści majątkowej przez sędziów cywilnych" ${ }^{11}$.

${ }^{8}$ Tab. 2,2: Morbus sonticus ... aut status dies cum hoste ... quid honum fuit unum iudici arbitrove reove, eo dies diffissus esto; Tab. 12,3: Si vindiciam falsam tulit, si velit is ... tor arbitros tris dato, eorum arbitrio ... fructus duplione damnum decidito; por. także G. 4,17a: actor dicebat: QUANDO TU NEGAS, TE PRAETOR, IUDICEM SIVE ARBITRUM POSTULO, UTI DES.

${ }^{9}$ M. KASER, K. HACKL, op. cit., s. 57.

"'Na temat innych aspektów officium iudicis, sankcji cywilnoprawnych (za litem suam facere) dotykających sędziego, który niewłaściwie wypełniał nałożone nań obowiązki oraz możliwości uniknięcia tychże (poprzez złożenie przysięgi sibi non liquere) por. J. ZABŁOCKI, Rozważania o procesie rzymskim, cit., s. 90 i n.; TENŻE, Appunti sull'officium iudicis' nelle 'Noctes Atticae', [w:] Au-delà des frontierès. Mélanges de droit romain offerts à Witold Wotodkiewicz, s. 1121 i n.

"Tak na przykład G. MACCORMACK, The Liability of the Judge in the Republic and Principate, «ANRW» II. 14 (1982), s. 4, który twierdzil, że jest wysoce prawdopodob- 
Problem korupcji związanej z działalnością trybunałów karnych (quaestiones extraordinariae i quaestiones perpetuae ${ }^{12}$ ) pojawia się dopiero w źródłach późnej republiki, które jednakże nie cytują przepisów Ustawy XII Tablic, co również świadczyć może przeciwko wspomnianej wyżej hipotezie.

Jak wynika ze źródeł, próby walki z korupcją sędziów sądów kryminalnych podejmowano w szeregu ustaw. Pierwszą $\mathrm{z}$ nich była tak zwana lex de pecunia accepta ob rem iudicandam z 141 r. p.n.e. Powodem wydania tej ustawy i powołania przez senat stosownego trybunału karnego było wzięcie łapówki przez pretora L. Hostiliusa Tubulusa, przewodzącego quaestio inter sicarios ${ }^{13}$. Nie jest jasne, czy został on przekupiony po to, aby skazać, czy też po to, aby uniewinnić. $\mathrm{Z}$ wielkiego oburzenia, jakie wywołała ta sprawa ${ }^{14}$,

ne, iż przekupstwo, o którym mowa w tablicy dziewiątej, dotyczyć miało spraw, w których wyrok odnosił się do caput podsądnego, albowiem pozostałe regulacje tejże tablicy odnoszą się do przypadków zagrożonych karą śmierci bądź utratą wolności.

12 Na temat tych trybunałów karnych por. W. KUNKEL, s. v. quaestio, «RE» 47 (1963); por. też W. MossakowsKI, Powotywanie sędziów quaestiones perpetuae w okresie republiki rzymskiej, «Acta Universitatis Nicolai Copernici» 304, Prawo 35 (1996), s. 69 i n.; W. LITEWSKI, Stownik encyklopedyczny, cit., s. v. quaestiones extraordinariae, quaestiones perpetuae.

${ }^{13}$ Cic., de fin. 2,16,54: An tu me L. Tubulo putas dicere? qui cum praetor quaestionem inter sicarios exercuisset, ita aperte cepit pecunias ob rem iudicandam ut anno proximo P. Scaevola tribunis plebis ferret ad plebe, vellentne de ea re quaeri. Quo plebiscito decreta a senatu est consuli quaestio. Cn. Caepioni; Cic., de nat. deor. 3,30,74: (quaestio) Tubuli de pecunia capta ob rem iudicandam. Co do możliwości powoływania quaestiones inter sicarios; por. J.L. STRACHAN-Davidson, Problems of the Roman Criminal Law, I, Amsterdam 1969, s. 227, przyp. 6; por. też TH. MoMMSEN, Römisches Strafrecht, Leipzig 1899, s. 197.

${ }^{14}$ Ascon., in Scaur. 20: Si me hercule, iudices, pro L. Tubulo dicerem quem unum ex omni memoria sceleratissimum et audacissimum fuisse accepimus ... Sam Tubulus udał się na wygnanie bez oczekiwania na proces. Asconius podaje (in Scaur. 20: ...de exilio arcessitus ut in carcere necaretur ...), że zostal on następnie aresztowany i popełnił samobójstwo; por. też. J.L. STRACHAN-DavidSON, op. cit., I, s. 228 i przyp. 2; G. Rotond, Leges publicae populi Romani, Milano 1912 (przedruk Hildesheim 1962), s. 296. 
można domyślać się, że chodziło raczej o przekupstwo w celu skazania niż uniewinnienia podsądnego. Konieczność wydania specjalnego plebiscitum i odnośnej uchwały senatu, by powołać quaestio mającą sądzić Tubulusa' ${ }^{15}$ wskazuje, iż branie lapówek przez sędziów nie było karane przez żadną istniejącą w owym czasie ustawę ${ }^{16}$.

Kilka lat później, w 123 r. p.n.e., trybun Gaius Sempronius Gracchus przeforsował lex Sempronia ne quis iudicio circumveniretur. Wiadomości, jakie mamy na temat tej ustawy, pochodzą prawie wyłącznie z mowy Cycerona pro Cluentio:

Cic., pro Cluent. 55,151: Atque ut omittam leges alias omnes, quibus nos tenemur, ceteri autem sunt ordines liberati, hanc ipsam legem: NE QUIS IUDICIO CIRCUMVENIRETUR, C. Gracchus tulit $^{17}$.

Większa część tej mowy jest poświęcona wykazaniu, iż Cluentio w sprawie, którą wniósł przeciwko swojemu ojczymowi Oppianicusowi, nie wręczył lapówki sędziemu w celu uzyskania wyroku skazującego. Położenie nacisku przez Cycerona na rzekome przekupstwo oskarżyciela i użycie przez niego słowa circumveni$r e^{18}$ świadczy, iż owa lex Sempronia nie dotyczyła wyłącznie przekupstwa sędziów i nie miała być środkiem zapobiegającym tego typu niewłaściwemu zachowaniu. Raczej była ona skierowana przeciwko wszystkim tym, którzy używali niedozwolonych środ-

'S Por. W. KUNKEL, Untersuchungen zur Entwicklung des römischen Kriminalverfahrens in vorsullanischer Zeit, München 1962, s. 45.

in J.M. Kelly (op. cit., s. 34) sugeruje, iż Tubulus mógl być sądzony na podstawie przepisów Ustawy XII Tablic, co nie wydaje mi się jednakże możliwe ze względów, o których pisałem wyżej na s. 28, 29.

${ }^{17}$ Istnieje kontrowersja, czy owa sprawa rzeczywiście wniesiona została przeciwko Cluentiusowi; por. G. PUgliesE, Aspetti giuridici della pro Cluentio di Cicerone, «lura» 21 (1970), s. 155 i n.; C.J. CLASSEN, Die Anklage gegen A. Cluentius Habitus (66 v. Chr: Geb.), «ZSS» 89 (1972), s. 1 i n.; TH. MOMMSEN, op. cit., s. 258.

${ }^{1 \times}$ Por. J. Sondel, Stownik lacinisko-polski dla prawników i historyków, Kraków 1997. s.v. circumvenio. 
ków w celu skazania oskarżonego w sprawie zagrożonej karą śmierci ${ }^{19}$.

Jak wynika za słów Cycerona, ustawa ta dotyczyła wyłącznie osób należących do stanu senatorskiego. Bez wątpienia więc dotyczyła ona również sędziów pochodzących z tego stanu, którzy skazali oskarżonego nie dlatego, iż był winien, ale dlatego, że otrzymali lapówkę ${ }^{20}$.

Natomiast pod rządami mającej krótki żywot kolejnej lex si quis ob rem iudicandam (iudicatam) pecuniam cepisset uchwalonej na wniosek trybuna Liviusa Drususa w 91 r. p.n.e. iudices wywodzący się $\mathrm{z}$ ordo equester byli odpowiedzialni za branie lapówek $\mathrm{z}$ tytułu wykonywanych przez siebie czynności ${ }^{21}$. Niejasny jest jednak zakres stosowania tej ustawy. Żadne ze źródeł bowiem nie wspomina, by stosowano ją wyłącznie do spraw zagrożonych karą śmierci bądź też wyłącznie do przypadków wręczenia lapówki sędziemu, aby ten skazał oskarżonego 22 .

$\mathrm{Z}$ kolei lex Cornelia de sicariis z 81 r. p.n.e. wprowadza regulację podobną do tej, którą znała cytowana lex Sempronia.

Cic., pro Cluent. 52,144: dixi Habito statim eo capite, QUI COISSET QUO QUIS CONDEMNARETUR, illum esse liberum: teneri autem

\footnotetext{
${ }^{19}$ Por. J.M. Kelly, op. cit., s. 35, 35.

"Por. U. EwINS, Ne quis iudicio circumveniatur, «Journal of Roman Studies» 50 (1960), s. 94 i cyt. tam lit.; E.S. GRUEN, Roman Politics and the Criminal Courts, 149-78 B.C., Cambridge 1968, s. 84 i n.; G. Pugliese, op. cit., s. 178 i n.; A.H.M. Jones, The Criminal Courts of the Roman Republic and Principate, Oxford 1972, s. 51 i n.; D. FLACH, Zur Strafgesetzgebung der gracchischen Zeit, «ZSS» 90 (1973), s. 98 i n.; Według K.F. ZuMPTA, Das Criminalrecht der römischen Republik, II. 2, Berlin 1869 (przedruk Berlin 1993), s. 28 i n., lex Sempronia znajdowała zastosowanie zarówno do privata, jak i publica iudicia; por. też J.L. STRACHAN-DAVIDSON, op. cit., I, s. 244, przyp. 1.

"Cic., pro Rab. Post. 7,16: M. Druso, novam in equestrem ordinem quaestionem ferenti si quis ob rem iudicandam pecuniam cepisset, aperte equites Romani restiterunt; por. J.M. KELLY, op. cit., s. 35.

"Na temat tej ustawy por. U. EwINS, op. cit., s. 104; C. NicolET, L'orde équestre á l'époque républicaine. Définitions juridiques et structures sociales, Paris 1966, s. 599 i n.; E.S. GRUEN, op. cit., s. 208.
} 
nostrum ordinem; 54,148: Quid eadem lex statim adiungit? Recita. DEQUE EIUS CAPITE QUAERITO. Cuius? qui coierit? convenerit? non ita est. Quid ergo est? dic. QUI TRIBUNUS MILITUM LEGIONIBUS QUATTUOR PRIMIS QUIVE QUAESTOR, TRIBUNUS PLEBIS. Deinceps omnes magistratus nominavit. QUIVE IN SENATU SENTENTLAM DLXIT, DIXERIT. qUid tuT? QUI EORUM COIIT, COIERIT, CONVENIT, CONVENERIT, QUO QUIS IUDICIO PUBLICO CONDEMNARETUR.

Cyceron cytował tę część (caput) ustawy, zgodnie z którą przeciwko magistratus bądź senatorowi, zmawiającym się w celu skazania oskarżonego w iudicium publicum, wytaczano stosowne postępowanie $^{23}$. Użycie przez Cycerona słów coitio i convenio w sposób jednoznaczny wskazuje, że owe knowania to zmowa urzędników czy też senatorów, mająca zapewnić skazanie oskarżonego². Jeśli więc sędzia wywodzący się ze stanu senatorskiego w gardłowej sprawie przyjmie łapówkę i skaże oskarżonego na karę śmierci², może zostać pociągnięty do odpowiedzialności na podstawie tej ustawy, o ile udowodniony zostanie nie tylko fakt przyjęcia przez niego korzyści majątkowej, ale i jego własny interes w wydaniu skazującego wyro$\mathrm{ku}$. Tego typu sprawy ścigane były przez quaestio de sicariis.

Natomiast o drugiej z ustaw wydanych przez Sullę, lex Cornelia de repetundis prawdopodobnie również z 81 r. p.n.e., wspomina Cyceron:

Cic., pro Rab. Post. 4,8-9: Iubet lex Iulia persequi ab eis, ad quos ea pecunia, quam is ceperit, qui damnatus sit, pervenerit ... sin hoc totidem verbis translatum caput est, quod fuit non modo in Cornelia, sed ante in lege Servilia ...

${ }^{23}$ Por. Th. Mommsen, op. cit., s. 633.

${ }^{24}$ Por. J. SONDEL, op. cit., s. v. coitio, convenio.

${ }^{25} \mathrm{Z}$ omówionych przez mnie niżej komentarzy Marcianusa do tejże ustawy (por. s. 35, 36) można wnioskować, iż w okresie, w którym ją wydano, chodzilo wylącznie o sprawy zakończone wyrokiem śmierci dla oskarżonego; por. też U. EwINS, op. cit., s. 96. 
Wydaje się do niej nawiązywać również we wspomnianej wyżej mowie pro Cluentio ${ }^{26}$, w której traktuje o oskarżeniu wniesionym przeciwko Falculi, jednemu z sędziów w sprawie, którą przeciwko Oppianicusowi wniósł Cluentius. Falcula został oskarżony o przyjęcie pewnej sumy pieniężnej od Cluentiusa. Cyceron twierdził, iż oskarżenie zostało wniesione w oparciu o lex de pecuniis repetundis, na które to prawo powoływano się w sprawach osób należących do stanu senatorskiego. Wynika z tego, że lex Cornelia de repetundis uważała przyjmowanie łapówek przez sędziów za przestępstwo, a ponadto, że znajdowała ona wyłącznie zastosowanie w stosunku do przekupnych senatorów.

Nie jest pewnym, czy owa ustawa zawierała szczegółowe przepisy o braniu łapówek przez sędziów czy też takie niewłaściwe zachowanie było podciągnięte pod jakiś generalny tytuł tyczący się niezgodnego z prawem otrzymywania korzyści majątkowej (zdzierstwo). Nie jest także jasne, czy prawo Sulli było pierwszym z leges repetundarum, które traktowało przyjęcie przez sędziego pieniędzy jako przestępstwo, czy też problemem tym zajęły się już wcześniejsze ustawy jak na przykład lex Acilia $^{27}$. Nie wydaje się natomiast, by warunkiem popełnienia tego przestępstwa było wręczenie łapówki w sprawie zagrożonej karą śmierci. Nie można bowiem wyciągnąć takiego wniosku wyłącznie $\mathrm{z}$ faktu, iż Falcula głosował za skazaniem Oppianicusa w sprawie zagrożonej karą śmierci ${ }^{28}$.

Sędzia, który był sądzony w oparciu o przepisy lex Sempronia bądź lex Cornelia de sicariis, powinien zostać skazany na śmierć, albowiem jego działanie prowadziło do śmierci niewinnej osoby, czyli mogło być traktowane jako zwykłe morderstwo, za które kara

${ }^{2 n}$ Cic., pro Cluent. 37,104: Qua lege in eo genere a senatore ratio repeti solet, de pecuniis repetundis, ea lege accusatus honestissime est absolutus.

${ }^{\prime 7}$ Była to uchwala zgromadzenia plebejskiego z 123 r. p.n.e. poświęcona przestępstwu repetundae, dla którego wprowadzała quaestio perpetua (stały trybunal karny) i szczególowe zasady postępowania przed nim; por. J.L. STRACHAN-DAVIDSON, op. cit., II, s. 6.

${ }^{2 k}$ Por. E.S. GRUEN, op. cit., s. 258. 
śmierci była jak najbardziej odpowiednia. W praktyce konsekwencją skazania było jednak tylko wygnanie i utrata obywatelstwa ${ }^{24}$. Jeżeli natomiast chodzi o kary przewidziane przez wcześniejsze leges repetundarum, to były nimi obok infamii kary pieniężne, nakazanie zwrotu przyjętych korzyści majątkowych, jak też połączenie wyżej wymienionych kar majątkowych ${ }^{30}$.

$\mathrm{Na}$ podstawie analizy przedstawionego wyżej prawodawstwa z okresu republiki co do korupcji sędziów można stwierdzić pewną ewolucję w zakresie katalogu karalnych zachowań i kategorii podlegających karze sędziów. Odnoszą się one jednak zasadniczo tylko do iudices orzekających w quaestiones, nie dotyczą natomiast tych, którzy orzekali w postępowaniu zwyczajnym.

W okresie wczesnego pryncypatu i prawdopodobnie aż do końca ery prawa klasycznego, odpowiedzialność sędziego regulowały przede wszystkim dwie ustawy: lex Cornelia de sicariis i lex Iulia de repetundis. Wszystkie posiadane przez nas fragmenty komentarzy jurystów do wyżej wymienionych ustaw pochodzą z okresu późnego prawa klasycznego. W szczególności do lex Cornelia odnoszą się trzy takie fragmenty, a najistotniejszym z nich jest komentarz Marcianusa:

D. 48,8,1 pr.-1 (Marc. 14 inst.): (pr.) Lege Cornelia de sicariis et veneficiis tenetur ... quive, cum magistratus esset publicove iudicio praesset, operam dedisset, quo quis falsum indicium profiteretur, ut quis innocens conveniretur ${ }^{31}$ condemnaretur. (1) Praeterea tenetur ... quive magistratus iudexve quaestionis ob capitalem causam pecuniam acceperit ut publica lege reus fieret.

W principium jurysta traktuje o coitio i convenio, o których wspominał również Cyceron w swych mowach o lex Cornelia de

?" Por. A.H.M. JonES, op. cit., s. 73.

" Por. W. KUNKEL, Zum römischen Strafverfahren und zur römischen Verfassungsgeschichte, I. 2: Quaestio, [w:] Kleine Schriften, Weimar 1974, s. 61, 66, 268; A.H.M. JONES, op. cit., s. 75.

"Cuiacius: circumveniretur. 
sicariis $^{32}$. W przeciwieństwie do niego Marcianus określił szerzej krąg osób, które mogły dopuścić się ściganych tymi ustawami przestępstw. W czasach Sulli i Cezara bowiem tylko senatorowie byli pociągani do odpowiedzialności. Natomiast na przełomie II i III wieku n.e. ${ }^{33}$ funkcje sędziowskie i różnego rodzaju urzędy mogły sprawować również osoby nie wywodzące się ze stanu senatorskiego.

Paragraf pierwszy odnosi się natomiast do przypadków wręczenia korzyści majątkowych. Użycie tutaj przez Marcianusa sformułowania quive magistratus iudexve quaestionis zdaje się wskazywać, iż jurysta cytuje oryginalne brzmienie ustawy, albowiem w czasach, w których żył, quaestiones wyszły już z użycia ${ }^{34}$. Dodanie na końcu tego paragrafu sformułowania ut publica lege fieret wskazywać by mogło, iż w pierwotnym brzmieniu ustawy samo przyjęcie korzyści majątkowej nie stanowiło wystarczającej przesłanki odpowiedzialności, lecz powstawała ona jedynie wtedy, gdy sędzia, który przyjął korzyść majątkową, wydał wyrok skazujący ${ }^{35}$.

Kolejnym tekstem odnoszącym się do lex Cornelia jest przytoczony w Digestach justyniańskich fragment monografii De officio proconsulis autorstwa Ulpiana:

D. 48,8,4 pr. (Ulp. 7 de off. procons.): Lege Cornelia de sicariis tenetur, qui, cum in magistratu est esset, eorum quid fecerit contra hominis necem, quod legibus permissum non sit.

Według komentującego tę ustawę Ulpiana odpowiedzialność sprawującego jurysdykcję karną magistratus powstaje w wyniku jakiegokolwiek działania tego ostatniego contra legem, które pociąga za sobą śmierć człowieka, a więc i jest niezależna od tego, czy wydał

\footnotetext{
Por. s. 32 i n.

3. Aelius Marcianus był jednym z ostatnich jurystów okresu klasycznego. Jego dzieła powstały w kilka lat po pracach Ulpiana, prawdopodobnie po śmierci cesarza Karakalli; por. W. LITEWSKI, Jurysprudencja rzymska, Kraków 2000, s. 145.

${ }^{34}$ Por. W. LITEWSKI, Stownik encyklopedyczny, cit., s. v. quaestiones perpetuae.

${ }^{35}$ Por. też G. Pugliese, op. cit., s. 177 i przyp. 33.
} 
on na przykład wyrok skazujący wskutek przyjęcia korzyści majątkowej.

Ostatnim z tekstów jest fragment Sentencji Paulusa:

PS. 5,23,11(10): Iudex qui in caput fortunasque hominis pecuniam acceperit, in insulam bonis ademptis deportatur.

Jurysta mówi, że sędzia biorący łapówkę jest odpowiedzialny niezależnie od tego, czy sprawa, którą prowadzi, jest zagrożona karą śmierciś.

$\mathrm{Z}$ powyższych fragmentów odnoszących się do zakresu stosowania lex Cornelia w okresie pryncypatu wynika, iż niemożliwym jest wskazanie kolejnych etapów rozwoju odpowiedzialności przekupnego sędziego. Można jedynie przypuszczać, że pierwotny zakres zastosowania ustawy do spraw zagrożonych karą śmierci, w których nastąpiło uniewinnienie oskarżonego, rozszerzono później na inne przypadki przestępstw. Należy tu zwrócić uwagę, że we wszystkich przytoczonych fragmentach, $\mathrm{z}$ wyjątkiem tekstu pochodzącego z Sentencji Paulusa, mowa jest o magistratus bądź o iudex quaestionis. W okresie republiki iudex quaestionis to zazwyczaj osoba, która piastowała wcześniej urząd edyla i przewodniczyła tej quaestio, której nie przewodniczył pretor ${ }^{37}$. Urząd ten nie jest natomiast znany w okresie poaugustiańskim prawdopodobnie dlatego, iż w owym czasie istniała wystarczająca liczba pretorów, którzy mogli przewodniczyć quaestiones perpetuae $^{38}$. Jeśliby zinterpretować znaczenie wyrażenia magistratus iudexve quaestionis $\mathrm{w}$ jego literalnym brzmieniu, to należałoby stwierdzić, iż lex Cornelia odnosiła się wyłącznie do tych sędziów, którzy przewodniczyli quaestiones, to znaczy wyłącznie do iudex quaestionis bądź później do sprawującego taką jurysdykcję pretora. Nie odnosiła się ona natomiast do pozostałych członków tego sądu, a także do nie zasiadających w quaestio członków consilium urzędnika (magistratus), który

i6 Tak G. MACCORMACK, op. cit., s. 11; przeciwnie E. LEVY, Gesetz und Richter im kaiserlichen Strafrecht, [w:] Gesammelte Schriften, II, Köln 1963, s. 438 przyp. 24.

${ }^{37}$ A.H.M. JONES, op. cit., s. 58; W. KUNKEL, op. cit., s. 55.

${ }^{38}$ W. KUNKEL, op. cit., s. 97. 
sprawował jurysdykcję karną w czasach cesarstwa. Dopiero bowiem Paulus w swych Sententiae mówi generalnie o iudex. Tak więc należy przyjąć, iż w okresie pryncypatu odpowiedzialność za przyjęcie korzyści majątkowej według lex Cornelia odnosiła się wyłącznie do posiadającego consilium magistratus bądź też iudex quaestionis.

Jeżeli natomiast chodzi o drugą ze wspomnianych wyżej ustaw, a mianowicie lex Iulia de pecuniis repetundis, to należy tu szczególną uwagę zwrócić na wypowiedź Macera w D. 48,11,7 pr. i D. 48,11,3, albowiem jak się wydaje, zawiera ona oryginalną treść owej ustawy:

D. 48,11,7 pr. (Mac. 1 iud. publ.): Lex Iulia de repetundis praecipit, ne quis ob iudicem arbitrumve dandum mutandum iubendumve ut iudicet: neve ob non dandum non mutandum non iubendum ut iudicet: neve ob hominem in vincula publica coiciendum vinciendum vincirive iubendum exve vinculis dimittendum: neve quis ob hominem condemnandum absolvendumve: neve ob litem aestimandam iudiciumve capitis pecuniaeve faciendum vel non faciendum aliquid acceperit.

D. 48,11,3 (Mac. 1 iud. publ.): Lege Iulia repetundarum tenetur, qui, cum aliquam potestatem haberet, pecuniam ob iudicandum vel non iudicandum decernendumve acceperit.

Tak więc stosownie do brzmienia legis Iuliae podlega karze ten, kto przyjąwszy pieniądze skarze, uniewinni bądź wyda inny wyrok, stosownie do życzenia wręczającego łapówkę. Należy zaznaczyć, że tą osobą może być nie tylko sędzia w sprawach karnych, lecz również w sprawach cywilnych (tak iudex jak i arbiter) ${ }^{34}$.

Równie istotny jest komentarz Macera do tejże ustawy, odnoszący się do jej stosowania w czasach mu współczesnych ${ }^{40}$ :

D. 48,11,7,3 (Mac. 1 iud. publ.): Hodie ex lege repetundarum extra ordinem puniuntur et plerumque vel exilio puniuntur vel etiam durius, prout admiserint. quid enim, si ob hominem ne-

${ }^{34}$ J.M. KELLY, op. cit., s. 37.

^) Por. O.F. Robinson, The Criminal Law of Ancient Rome, London 1996, s. 82. 
candum pecuniam acceperint? vel, licet non acceperint, calore tamen inducti interfecerint vel innocentem vel quem punire non debuerant? capite plecti debent vel certe in insulam deportari, ut plerique puniti sunt.

Wynika z niego, iż ponosić odpowiedzialność będzie również i ten sędzia, który powodowany gniewem i złością skazał na śmierć oskarżonego, mimo iż powinien go uniewinnićc ${ }^{41}$. Nie oznacza to jednak, iż sędzia odpowiadał w każdym przypadku, gdy wydał niesprawiedliwy wyrok. Narażał się on bowiem na oskarżenie jedynie wówczas, gdy w sposób niedostateczny rozpatrzył wszystkie dowody albo gdy istniała wyraźna dysproporcja między popełnionym przestępstwem a wymierzoną zań karą. Pozostaje natomiast kwestią otwartą, czy tego rodzaju odpowiedzialność sędziego ograniczona była wyłącznie do przestępstw zagrożonych karą śmierci. Wprawdzie Macer wspomina o sędzim, który skazał oskarżonego na śmierć, ale nie wiemy, czy był to jedyny przypadek odpowiedzialności.

W czasach, gdy żył Macer, quaestiones przestały funkcjonować, dlatego też zmienił się krąg osób, które mogły zostać oskarżone na podstawie owej ustawy. Tutaj również powstaje kwestia, czy odpowiedzialnym był wyłącznie wyrokujący (na przykład praefectus urbi) czy także osoby wchodzące w skład towarzyszącego mu consilium. Odpowiedzi twierdzącej na to pytanie zdaje się udzielać sam jurysta:

D. 48,11,5 (Mac. 1 iud. publ.): In comites quoque iudicium ex hac lege iudicium datur.

A zatem, jak możemy wnioskować, oprócz sprawującego jurysdykcję karną magistratus odpowiedzialność ponosił również towarzyszący mu personel (comites) ${ }^{42}$.

${ }^{\prime}$ Por. też G. von Beseler, Beiträge zur Kritik der römischen Rechtsquellen, I, Tübingen 1910, s. 68.

${ }^{2}$ Według Th. Mommsena (Die comites Augusti der früheren Kaiserzeit, [w:] Gesammelte Schriften, IV, Berlin 1906, s. 314 i przyp. 2), owo comitium to wyłącznie asesorzy sprawującego jurysdykcję namiestnika prowincji; por. też O.F. RoBINSON, op. cit., s. $81,82$. 
$\mathrm{Z}$ kolei Paulus stwierdza, że odpowiedzialnymi są również iudices pedanei (sędziowie delegowani) ${ }^{43}$ :

PS. 5,28B,2(1): Iudices pedanei si pecunia corrupti dicantur, plerumque a praeside aut curia submoventur aut in exilium mittuntur aut ad tempus relegantur.

Sumując dotychczasowe rozważania na temat prawnokarnej odpowiedzialności sędziego źle wypełniającego swoje officium w okresie pryncypatu, należy zauważyć, że istniały jej dwie kategorie w przypadkach, w których nie wchodziło $w$ grę przyjęcie łapówki przez sprawującego jurysdykcję, a mianowicie na podstawie lex Cornelia, gdy brał on udział w zmowie mającej na celu doprowadzenie do skazania niewinnego, natomiast na podstawie lex Iulia, gdy osoby wykonujące jurysdykcję dopuściły się wydania rażąco niesprawiedliwego wyroku. Z kolei przypadki przyjęcia korzyści majątkowej były ścigane przez obydwie te ustawy, przy czym lex Cornelia odnosiła się wyłącznie do magistratus i do sprawujących jurysdykcję sędziów, początkowo wyłącznie w sprawach zagrożonych karą śmierci, natomiast lex Iulia dopuszczała możliwość oskarżenia kogokolwiek, kto orzekał, niekoniecznie pełniąc funkcję sędziego, w jakimkolwiek procesie.

Kara za opisane wyżej przestępstwa zależała częściowo od procedury, stosownie do której wniesiono oskarżenie, a po części od kategorii społecznej, z której wywodził się sędzia. I tak, jeżeli oskarżenie wniesiono przed stosowną quaestio, kara zależała wyłącznie od ustawy, na której oparto owo oskarżenie i sąd nie miał w tym przypadku żadnej swobody w określeniu jej wymiaru. Natomiast, jeżeli oskarżenie wniesione zostało przed senatem bądź przed magistraturą wykonującą cognitio, kara mogła być różna, to znaczy niekoniecznie ta$\mathrm{ka}$, jaką przewidywała ustawa stanowiąca podstawę oskarżenia ${ }^{44}$.

${ }^{+3}$ Iudex pedaneus (iudex delegatus, iudex datus) była to w postępowaniu kognicyjnym osoba, zwykle ktoś z pomocniczego personelu sędziego, której ten ostatni przekazal rozpoznanie sprawy i wydanie wyroku.

${ }^{\star}$ Por. A.H.M. JonES, op. cit., s. 73. 
Według Paulusa lex Cornelia de sicariis przewidywała deportację na wyspę i konfiskatę majątku ${ }^{45}$, natomiast podstawową karą przewidzianą w lex Iulia de pecuniis repetundis, stosownie do przekazu komentującego ją Macera, było wygnanie. Z kolei w przypadku cięższych przestępstw, takich jak przyjęcie korzyści majątkowej i skazania niewinnej osoby na śmierć, karą była śmierć lub deportacja na wyspę $^{46}$. Iudices pedanei ryzykowali wydaleniem $\mathrm{z}$ kurii, do której należeli bądź wygnaniem ${ }^{47}$.

W okresie pryncypatu do odpowiedzialności sędziego stosowano również wydaną przez Sullę lex Cornelia testamentaria nummaria (de falsis) z 81 r. p.n.e., która pierwotnie odnosiła się do przypadków podrobienia testamentów i fałszerstwa monet. W okresie prawa klasycznego rozszerzony został zakres jej stosowania drogą konstytucji cesarskich, uchwał senatu i interpretacji tejże ustawy przez jurystów $^{18}$. Oprócz wyżej wymienionych dwóch przypadków odpowiedzialności wprowadzone zostały kolejne: danie oraz przyjęcie korzyści majątkowej w celu przedstawienia fałszywych dowodów oraz wręczenie łapówki sędziemu ${ }^{49}$, przy czym przyjęcie łapówki przez sędziego nie było tutaj traktowane jako odrębne przestępstwo ${ }^{50}$, gdyż za takie uważano lekceważenie przez sędziego konstytucji cesarskich.

45 Por. PS. 5,23,11(10) cyt. na s. 37; deportacja byla przymusowym osiedleniem na wyspie (lub w pustynnej oazie). W razie samowolnego opuszczenia wyznaczonego miejsca grozila kara śmierci.

th Por. D. $48,11,7,3$ cyt. na s. 38.

${ }^{47}$ Por. PS. 5,28B, 2 (1) cyt. na s. 40.

*' Por. A. D’Ors, Contribuciones a la historia del crimen falsi, [w:] Studi in onore di E. Volterra, II, Milano 1971, s. 572.

${ }^{\prime \prime}$ D. 48,10,1,2 (Marc. 14 inst.): Sed et si quis ob renuntiandum remittendumve testimonium dicendum vel non dicendum pecuniam acceperit, poena legis Comeliae adficitur; PS. 5,25,2: Qui ob falsum testimonium perhibendum vel verum non prohibendum pecuniam acceperit dederit iudicemve, ut sententiam ferat vel non ferat, corruperit comumpedumve curaverit, humiliores capite puniuntur, honestiores publicatis bonis cum ipso iudice in insulam deportantur; por. też O.F. RoBINSON, op. cit., s. 37.

s" Przeciwnie A. Berger, Encyclopedic Dictionary of Roman Law, Philadelphia 1953, s.v. falsum; por. też E. LEVY, op. cit., s. 438 i przyp. 24. 
D. 48,10,1,3 (Marc. 14 inst.): Sed et si iudex constitutiones principium neglexerit, punitur.

PS. 5,25,4: Iudex, qui contra sacras principium constitutiones contrave ius publicum, quod apud se recitatum est, pronuntiat, in insulam deportatur.

A zatem według Marcianusa ukarany zostanie sędzia, który w wyniku swej neglegentia nie zastosował się do norm ustanowionych przez konstytucje cesarskie. Więcej informacji dostarcza natomiast na ten temat Paulus, który wprowadza rozróżnienie na constitutiones principum i ius publicum, rozważając przypadek, w którym sędzia nie bierze pod uwagę regulacji zawartych w konstytucjach cesarskich. Musiał on to jednak czynić rozmyślnie, a nie wskutek nieznajomości ich treści. Nic jurysta natomiast nie wspomina o tym, czy sędzia mógł być pociągnięty do odpowiedzialności w przypadku, w którym nie zastosował się on do norm ius publicum $\mathrm{z}$ uwagi na ich nieznajomość.

Lex Cornelia testamentaria przewidywała w przypadku skazania humiliores karę śmierci. Honestiores byli traktowani łagodniej, gdyż za popełnienie przestępstwa groziła im tylko konfiskata majątku i wygnanie połączone $\mathrm{z}$ utratą obywatelstwa ${ }^{51}$.

\section{The Criminal Llability of a Judge Wrongly FULFILLING HIS OFFICIUM}

\section{Summary}

Bribing judges was an indispensable element of the lawsuits, especially criminal, which is reflected both in the acts issued to prevent bribery and the literature.

The oldest regulations concerning this issue are included in the Law of the XII Tables, which were handed down by Aulus Gellius. It is evident

\footnotetext{
s Por. PS. 5,25,2 cyt. w przyp. 49.
} 
from this Law that iudex or arbiter who adjudged in favour of the person from whom he received money, was sentenced to death. The issue of corruption appears also in the sources of the late republic. It is evident that the attempts to fight against the judges' corruption were made in a series of acts, among others, in lex Sempronia ne quis iudicio circumveniretur. This act concerned only those who had the senatorial status and who sentenced the accused not because he was guilty but because they were bribed. In the period of the early principate and probably until the end of the classical law era, the liability of the judge was regulated above all by two acts: lex Cornelia de sicariis and lex Iulia de repetundis. However, on the basis of the passages referring to the scope of applying lex Cornelia in the principate period it appears that it is impossible to point the particular stages of the development of a corruptible judge's liability. It can be only supposed that the original scope of the act's applicability to the cases threatened with a death sentence in which the acquittal of the accused was adjudged, was later broadened to other crimes. Whereas, on the basis of legis Iuliae the one who, after taking a bribe, sentenced, acquitted or gave yet another verdict in compliance with the briber's wish, was liable to a penalty. It should be stressed that this law referred not only to judges in criminal cases but also in civil ones (iudex as well as arbiter). According to Paulus who comments on the act, lex Cornelia de sicariis provided deportation to an isle and confiscation of the property, whereas the penalty provided for in lex Iulia de pecuniis repetundis, as reported by Macer, was an exile. In case of more serious crimes such as accepting property benefit and passing a death sentence to an innocent person, the penalty was death or deportation to an isle. Iudices pedanei provided for dismissal from the curia to which the judge belonged to or an exile. In the period of principate lex Cornelia testamentaria nummaria (de falsis) dated $81 \mathrm{BC}$, issued by Sulla, was applied to the liability of a judge. This act originally referred to cases of forging wills and coins and later also to cases of giving and receiving property benefits to present false evidence and bribe a judge. Lex Cornelia testamentaria provided for a death sentence in case of sentencing humiliores. Honestiores were treated in a more mild way since they were sentenced to the confiscation of property and exile with deprivation of citizenship. 